\title{
Artium
}

Architecture, Urbanism, Design and Construction Vol. 10, Issue 1, February 2022

Journal homepage: http://artium.hku.edu.tr

DOI: $10.51664 /$ artium.980509

\section{Aşçılık ve Gastronomi Eğitim Kampüsü Tasarımının Mimari Bağlamda İrdelenmesi}

\author{
Mine TUNÇOK SARIBERBEROĞLU ${ }^{1}$ \\ 1 Dr. Öğr. Üyesi, Bolu Abant İzzet Baysal Üniversitesi, Mimarlık Fakültesi, \\ mine.tuncoksariberberoglu@ibu.edu.tr, ORCID ID: 0000-0002-6931-0539
}

\section{Öz}

\begin{abstract}
Üniversite kampüsleri özellikle Anadolu kentleri özelinde ele alındığında eğitim, üretim, konaklama, dinlenme, ulaşım gibi farklı işlevlere sahip olmalarının yanı sıra sosyal etkileşimin kurulduğu yerleşim yerleri olarak önemli alanların başında yer almaktadır. Bolu İli Mengen İlçesi için de üniversite kampüsü olgusu sıradan bir eğitim alanından ziyade ilçenin aşçılık ve gastronomi kültürünü yaşatacağı ve gelecek nesillere aktaracağı temel yapı taşlarından birini oluşturmaktadır. İnsan ölçeğinden kentsel ölçeğe potansiyel kullanıcı ihtiyaçlarını anlamayı ve ihtiyaçların karşılandığı yaşanabilir mekânlar oluşturmayı hedefleyen mimarlık pratiği sadece yapılı bir sistem olmanın dışında oluşturduğu mekânsal düzen ile de bir kimlik tanımlamaktadır. Mekânlar ile kurulan duyuşsal, bilişsel ve sosyal etkileşimler bu kimlik üzerinden inşa edilir. Dolayısıyla fiziksel mekânın temel ihtiyaçlarının karşılanması ile mekânsal düzenin niteliği de en temel mimari tasarım problemini oluşturmaktadır. $\mathrm{Bu}$ makalede Bolu Abant İzzet Baysal Üniversitesi Mengen Aşçılık ve Gastronomi Eğitim Kampüsünün kültür ve sosyal yaşam ekseninde sahip olduğu kimliği oluşturan mimari tasarım kriterleri sunulmaktadır.
\end{abstract}

Araştırma Makalesi Research Article

\section{An Architectural Analysis of Culinary and Gastronomy Education Campus Design}

\begin{abstract}
University campuses especially in Anatolian cities are considered as the most important settlements where social interaction is established, as well as working, sheltering, recreation, and transportation. For the Mengen district of Bolu province, the university is considered as the main area which will keep the culinary and gastronomy culture alive and transfer to future generations, rather than an ordinary education. Architectural practice, which aims to understand potential user needs from human scale to urban scale and to create livable spaces where needs are met, defines an identity with the spatial order it creates, apart from being a built system. The effective, cognitive, and social interactions that each individual establishes with the spaces are built on this identity. This article focuses on the architectural design criteria that form the identity of Bolu Abant İzzet Baysal University Mengen Culinary and Gastronomy Education Campus on the basis of culture and social life.
\end{abstract}

MAKALE BILGISI

Geliş: 09 / 08 / 2021 Kabul: 23 / $10 / 2021$
ANAHTAR KELIMELER

Așçıllk ve Gastronomi

Eğitim Yapıları

Mimari Kimlik

Mimari Tasarım

\author{
ARTICLE HISTORY \\ Received: 09 / 08 / 2021 \\ Accepted: $23 / 10 / 2021$ \\ KEYWORDS \\ Culinary \& Gastronomy \\ Educational Buildings \\ Architectural Identity \\ Architectural Design
}

\section{Gíriș}

Üniversite kampüsleri kentlere benzer olarak çalışma, barınma, ulaşım ve serbest aktivite gibi çeşitli fonksiyonlarla sosyal etkileşimin sağlandığı yerleşkeler olarak karşımıza çıkmaktadır (Yıldız ve Şener, 2006). Fiziksel gerçekleri ortaya koyarak toplumun gelişimini yansıtan kampüsler, eğitimsel dünya görüşü anlayışının gelişmesine olanak sağlayan yerlerdir (Düzenli ve diğ, 2017). Bulundukları kent ile sosyo-kültürel ve ekonomik yönden sürekli bir etkileşim içerisine giren üniversiteler, sahip oldukları tesislerin de o kentte yaşayan insanlar tarafindan kullanılması aracıllğı ile kent ve üniversite arasında doğrudan bir ilişki kurulmasına neden olmaktadır (Erkman,1990).

Doğrudan kent merkezinde yer alan kent içi kampüs alanlarının yanı sıra gündelik hayatın yoğunluğundan uzaklaşarak doğaya yakınlaşıldı ğı, aynı zamanda fiziksel planlama ile kendine ait sistemler oluşturabilen bir mikro kozmos olan kent dışı kampüs alanları (Turner, 1990), kent ile iletişim içerisinde olarak toplumun kampüsün açı alanlarından yararlanmasına olanak sağlama potansiyeline sahiptir (Ayvac1, 2009). Başka bir ifadeyle, üniversiteler, bulundukları kentlerde yeni kültürel, sportif ve eğlence alanlarının oluşmasına olanak sağlamakta, farklı 
şehirlerden ve geçmişlerden gelen öğrencilerin yöre haklı ile kurduğu etkileşimler neticesinde, o kentin sosyokültürel olarak da gelişmesine olanak sağlamaktadır (Yavuzçehre, 2016).

Üniversiteler sahip oldukları eğitim ve araştırma programları ile ulusal ve uluslararası düzeyde etkileşimin en yüksek olduğu yerler olarak özgün nitelik sahibi programları ile de öne çıkabilmektedir. Üniversitelerde gerçekleştirilen bilgi üretiminin kent ve toplum ile kurduğu ilişkinin güçlü olduğu durumlarda kentüniversite-kimlik ilişkisinin güçlü etkileşimleri görülebilmektedir.

$\mathrm{Bu}$ etkileşimin etkin olarak gerçekleşebileceği alanlardan biri olan Aşçılık ve Gastronomi dalı üniversite eğitimi ve kampüs hayatı söz konusu olduğunda kendine ait mekânsal gereksinimlerinin yanı sıra kültürel miras aktarımı sağlaması ile de öne çıkmaktadır. İnsanın beslenmesi çerçevesinde yaşam kalitesini kapsayan her alanda detaylı bilgi birikimi olarak tanımlanan gastronomi, tüm özelliklerini tarihsel gelişim sürecinden başlayarak ayrıntılı bir biçimde ele alan bir bilim dalıdır. Aynı zamanda gastronomi, tarihi süreçte geliştirilerek kullanılmaya devam eden yöntemlerin anlaşılması, uygulanması ve tekrar günümüz koşullarına uyarlanması süreçlerini içeren bir tanıma sahiptir (Sarışık ve Özbay, 2015).

Blank (2003) tarafindan "Iyi yemek yemenin bilimi ve sanatı" olarak ifade edilen gastronomi sadece varlığını sürdürmek için gelişi güzel yemek ve içmek anlamına gelmemekle birlikte insanın ve estetiğin odağında konumladığ 1 geniş bir konudur. Kültür ve turizm alanında büyük bir ivmeyle öne çıkan gastronomi, işletmelerin ve eğitim kurumlarının da ülkeler kadar yerel yemek kültürüne sahip çıktığı, yemeği bir görsel sanata dönüştürmek ve yemeği kaliteli üretmek adına önem verdiği bir alandır (Öney, 2016).

Sahip olduğu bilimsel yaklaşımların yanı sıra sanatsal ve kültürel felsefeleri de kapsayan gastronomi, ülke mutfaklarını birer marka değerine sahip olmasına da olanak sağlamaktadır. Ülkemiz özelinde de yemek kültürü bilim ve eğitim kurumları tarafindan önemsenmeye başlanmış ve gastronomi bölümleri turizm yüksekokullarının, fakülteye dönüştürülme hamleleri ile bilimsel ve felsefi yönden yeni bakış açıları geliştirilmesinin önünü açmıştır (Öney, 2016). 2 yıllık bir ön lisans aşçılık programı ile aşçı olunabilirken, 4 yıllık lisans gastronomi eğitiminin ardından gastronom olarak mezun olunabilmektedir.

Kuşaktan kuşağa yemek yapma eyleminin bir meslek olarak görüldüğü ve bu yöreden çıkan aşçıları ile ülke kapsamında belirli bir tanınmışlığa sahip olan Bolu ili Mengen İlçesi dünya genelinde kabul gördüğü bir aşçılık kimliğine sahiptir. Aşçılık meslek olarak ilçenin en çok değer verdiği geçim ve tanınma kaynağıdır. İl genelinde de Mengen Aşçılar Otelcilik ve Turizm Meslek Lisesi; Abant İzzet Baysal Üniversitesi Mengen Meslek Yüksekokulu Aşçılık Programı; Bolu Turizm İşletmeciliği ve Otelcilik Yüksekokulu Gastronomi ve Mutfak Sanatları Bölümü gibi farklı kademelerde yer alan eğitim birimleri ile kültürün dünya çapında sürdürülebilmesi desteklenmektedir. Yine bu doğrultuda her sene Mengen Aşçılar ve Turizm Festivali ile bölgede yetişmiş İstanbul, Ankara, Antalya ve İzmir gibi büyük kentlerdeki ünlü otellerde çalışan aşçıların bir araya gelebildiği bir festivale ev sahipliği yapmaktadır (Hoşcan ve diğ, 2016).

Kent kimliği ile kente özgü unsurlar anlamlı bir bütün oluşturarak kentin değerini arttırır (Birol, 2007) ve yöresel festivaller de kent kimliğinin bir parçasıdır. Küçük kentlerde üniversite bünyesinde farklı kesimlerin buluştuğu ortamları oluşturması açısından önemli olan festivallerin, dünyanın pek çok yerinde kırsal turizmi hareketlendirerek yerel ekonomiyi canlandırma potansiyelinin yanı sıra, bölgeye sağladığı sosyo-kültürel katkılar ile eski geleneklerin yaşatılarak toplumsal birlikteliğin sağladığını ortaya koyan çalışmalar yer almaktadır (Erdem ve diğ, 2018).

2018 yılı itibariyle Mengen ilçesi içerisinde yer alan Bolu Abant İzzet Baysal Üniversitesine bağlı aşçılık ve gastronomi birimlerinin tek bir çatı altında toplanması ve kent/ülke kültürünün bir parçası haline gelmiş Mengen Aşçılık Festivalini destekleyen bir yaklaşım fikri ortaya çıkmıştır. Bu doğrultuda da İzzet Baysal Vakfı tarafından finanse edilen Mengen Așçılık ve Gastronomi Eğitim Kampüsü Projesi gündeme gelmiştir. Bu durum kendine ait mekânsal bir kimliğe sahip olan aşçılık ve gastronomi fakülte binaları, gereken eğitim ortamlarının yanı sıra açık ve kapalı sosyal etkileşim ortamlarının da gereksiniminin duyulduğu bir mimari tasarım problemi olarak karşımıza çıkmaktadır.

$\mathrm{Bu}$ çalışma kapsamında, ülkenin aşçılık kültürüyle öne çıkan özel bir bölgesinde yer alan Bolu Abant İzzet Baysal Üniversitesi Mengen Aşçılık ve Gastronomi Kampüsü mimari tasarım süreci aktarılmaya çalışılmaktadır. Söz konusu tasarım bağlamında mekânsal tasarıma dair temel yaklaşımlar üzerinde durularak, mimari avan ve uygulama projelerinin tasarım ilkeleri sunulmaktadır.

\section{KAVRAMSAL YAKLAŞIM}

Her kültür kendine ait sembollere sahiptir ve bu sembollerin başında mekân anlayışı ve kullanışı gelir. Fiziksel çevrenin bir elemanı olan mekân aynı zamanda bireyleri de biçimlendiren ve geleceğimize yön veren bir araç olarak ele alınabilmektedir (Kol, 2003). Bu bağlamdan bakıldığında bireylere kim olduklarını ve toplum içinde kim olabilecekleri konusunda çeşitli mesajlar verme potansiyeline sahip tasarlanmış fiziksel çevreler olan eğitim mekânları bireylerin de kendilerini özdeşleştirerek belirli birer kimlik kazanmalarına olanak sağlamaktadır (Tunçok Sarıberberoğlu, 2018). Anadolu kentlerinde gerçekleştirilen mimarlık üretimi de kent, kültür ve kimlik kavramları çerçevesinde ele alınması gereken tasarım problemlerini oluşturmaktadır.

Seamon (1982; 1987), yerlerin, mekânların ve çevrelerin günlük deneyimlerini analiz ederek kişi-mekân ilişkisinin boyutlarını tanımlar ve içeridelik-dışarıdalık diyalektiğinin mekân deneyiminin temel özü olduğunu belirtir. Norberg-Schultz (1980), yer kavramını aidiyet duygusu, yönelim ve özdeşleşme duyguları üzerinden ele alır ve bir yerin özü o yerin "atmosferi"dir, dolayısıyla o yerin yapısı peyzaj, yerleşim, mekân ve karakteri ile tanımlanır. 
Gelişen, hareketli ve uzun ömürlü kuruluşlar olan üniversiteler, bulundukları yöreleri de yapısal biçimlenmeleri, onları çevreleyen açık alanları, iç ve dış mekân kullanımının işlevselliği ile etkileyip dönüştürme potansiyeline sahiplerdir. Eğitim, çalışma, barınma, ulaşım gibi temel fonksiyonların yanı sıra açık alan kurguları ile sosyal hayatı şekillendiren mekânlara sahip olmaları kampüs yaşantısının gündelik hayat ile ilişki kurduğu ara kesitlere olanak sağlayabilmektedir.

Bulunduğu kentin siluetini ve yaşamını değiştirme potansiyeline sahip olan kampüsler, öğrencilerin belirli bir süre hayatlarını geçirdikleri ve meslekleri ile ilgili donanımları edindikleri yerler olmalarının yanı sıra ögrencilerin aidiyet hissinin geliştiği ve yeni anlamlar üzerinden anılarında izler birakan yerler olarak da karşımıza çıkmaktadır (Yılmaz, 2015; Broussard, 2009; Yalçın, 2012). Kampüslerin ve kampüsleri oluşturan binaların sahip oldukları mekânsal düzen tasarlanma biçimi ile aidiyet-kimlik- bağlılık gibi kavramlar bağlamında anahtar niteliği taşımaktadır.

Kampüs kurgusunun ana unsuru olan eğitim binalarının mekânsal kurguları da dersliklerin doğrusal veya küme düzenlemelerinde gruplanma biçimine göre Perkins (2001) tarafından dört temel kategoriye ayrılmıştır (Şekil 1). Bölgelerin birbirlerine genel konumu veya yönlendirilmesine dayanan bu sinıflandırmada; (1) ortak veya sınıf alanlarının merkezileştirilmesine dayanan konfigürasyon; (2) avlu diğer işlevlerle çevrili model; (3) omurga sistemi ve (4) farklı mekânsal birimleri için ayrı binalardan oluşan ve dış mekân sirkülasyon alanları aracılığıyla bağlanan merkezi plan modeli bulunmaktadır (Tunçok Sarıberberoğlu, 2018).

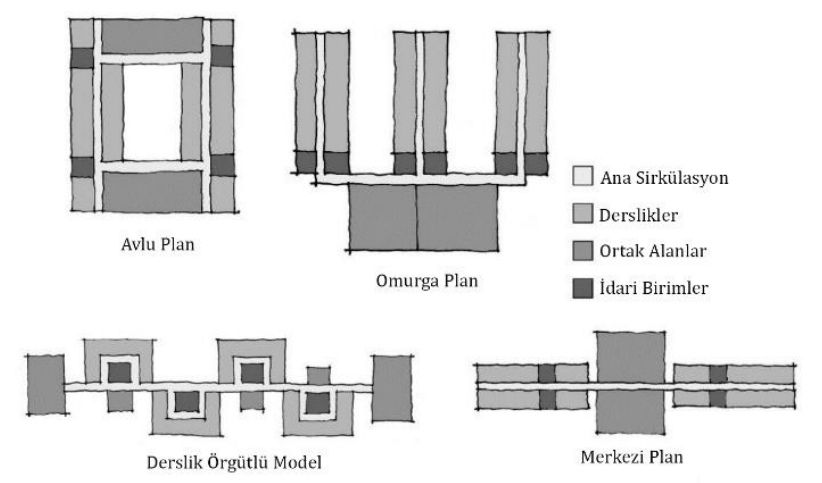

Şekil 1. Perkins'in okul binası düzenlerinin sinıflandırılmasından örnekler (Perkins, 2001; Tunçok Sarıberberoğlu, 2018).

Farklı tasarım kararları ile şekillenen eğitim binalarının bir araya gelerek oluşturduğu kampüs kurgularından, bütüncül tasarım kararları ile oluşturulmuş kampüs sistemlerine kadar pek çok farklı yaklaşımı ülkemiz genelindeki üniversite yerleşkelerinde gözlemlemek mümkündür. Her bina kendi özelinde bir tasarım problemi olarak ayrı ele alındığında mekânsal biçimlenmesinin de o probleme özgü olarak avlu plan, omurga plan ya da merkezi plan gibi farklı yaklaşımlarla şekillenmesi olasıdır. Bununla birlikte bütüncül kampüs tasarımı olarak ele alınan sistemlerde de temel bir yaklaşım üzerinden kampüs kurgusu oluşturulmaya çalışıldığ 1 ve eğitim binaları özelinde de ana kurguya sadık kalındığ görülebilmektedir. İster tekil çözümlemeler ister bütüncül yaklaşımlar olsun dünya genelindeki yaklaşımlara bakıldığında genel olarak eğitim binalarının mikro ölçekte toplumlar olarak öngörüldükleri ve toplumsal kent yaşamının birer parçası olarak tasarlandıklarını söylemek mümkündür.

Kampüs yerleşimlerinin yapısal kararları açık alan kullanımı etkileyen faktörlere bakıldığında mekânın biçimi, boyutları, tanımı, ulaşılabilirliği (Whyte, 1980), dış mekânların binalardan daha değişken kullanım örüntüleri (Friedman ve diğ., 1978), dış mekâna doğrudan bağlantısı olan kamusal yüzlerin geçirgenliğinin sağlanması ile kamusal ve özel yaşam arasındaki ilişkinin desteklendiği (Gehl, 1987), yaklaşımlar tasarlanan nitelikli sosyal yaşam alanları oluşması açısından son derece önemlidir (Yıldız ve Şener, 2010). Etkili kampüs tasarımında "mekân, amaç, düzen ve kalite "hissinin görsel olarak sağlanması gerekliliği Griffith (1994), o mekânın nasıl algılandığı üzerinde etkili bir faktör oluşturmaktadır. İnsanların açık mekânların fiziksel niteliklerini nasıl algıladıkları, o mekânları nasıl kullandıkları ile ilişkilidir (Düzenli ve diğ 2017).

Biçimlerine ve işlevlerine göre farklı kategorilerde değerlendirilebilen kampüs kurguları, bir çok farklı çalışmada da sosyal alanların biçimsel durumlarının mekânsal karşılıkları üzerinden ele alınmaktadır (Birinci ve diğ, 2020; Erçevik ve Önal, 2011; Ayvac1, 2009; Yılmaz, 2015) Kampüs kurgularındaki yapıların yerleşim şekillerinin işleve ve biçime dayalı kategorize edilmesinin yanı sıra açık alan kurguları da merkezi açık alanlar, odaklanmış açık alanlar, doğrusal/lineer açık alanlarkoridorlar, organik- doğrusal/lineer açık alanlar (Şekil 2) alt başlıklarında ele alınmaktadır (Düzenli ve diğ., 2017).

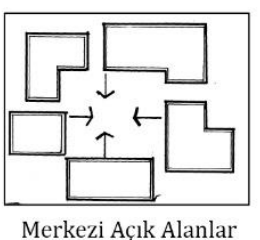

Merkezi Açık Alanlar

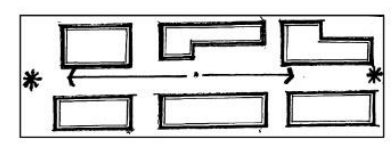

Doğrusal Açık Alanlar

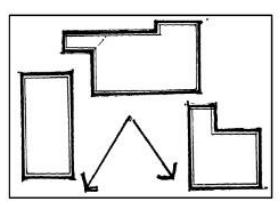

Odaklanmıș Açık Alanlar

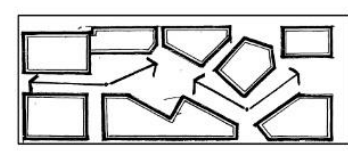

Organik Doğrusal Açık Alanlar
Şekil 2. Kampüs açık alan tipleri (Düzenli ve diğg, 2017).

Yapıların merkez bir nokta etrafında konumlandırılması ile ortaya çıkan yerleşim tipinde açık alanlar ana toplama ve buluşma yerleri olarak karşılık bulurken, bir kısmı açık bırakılacak şekilde tam kapalı olmayan yaklaşımlar odaklanmış açık alanlar olarak tanımlanmaktadır. Açık bırakılan alanın ölçüsü alanın algılanmasında önemli bir role sahiptir. Açık kenar yönünde manzara odaklanan bu yerleşimde bırakılan boşluk fazla açıldığında tanımlı mekân algısı da kaybolur. Dar ve uzun olarak tanımlanabilen doğrusal açık alanlarda ise her iki uç açıktır. $\mathrm{Bu}$ tür alanlarda oluşan açık alan ile görüşün ve mekânsal algının kaybolması söz konusu değildir. Doğrusal mekânlardan farklı olarak kurgulanan organik 
doğrusal açık alanlar da ise diğer ucun görünmediği, farklı bakış açıları ortaya çıkmaktadır (Düzenli ve diğ, 2017).

Kampüs planlaması söz konusu olduğunda etkili bir tasarımın bir alt başlığı da bünyesindeki yapıların tasarım kriterleridir. Açık mekânlar ile kapalı mekânların yatayda ve dikeyde ilişkisi genel kampüs kurgusunun da nasıl algılandığı, kişilerin mekânlarda nasıl vakit geçirdiklerini belirleyen bir unsurdur.

\section{TASARIM ARACI OLARAK MEKÂNSAL DİZIM}

Mekânsal düzenin insanları bir araya getirme ve ayrıştırması üzerine gerçekleştirilen çalışmalarda mimari tasarım kimlik, bağlam ve yer ilişkisi kapsamında ele alınarak ve pek çok farklı teoriler ile desteklenerek sinanabilmekte ve elde edilen veriler tekrar tasarım problemi çözümlemelerinde başvurulan yöntemlere dönüşebilmektedir.

İnsanlar tarafından biçimlendirilmiş mekânların nasıl yapılandırıldığını, işlediğini, anlaşıldığını, toplumun bir parçası haline geldiğini ve tüm bunların işlevsel sonuçlarını araştıran teorik bir model olan mekân dizimi teorisine göre konfigürasyon, yani mekânsal sistemdeki birimin sistemdeki diğer tüm birimlere göre olan konumunun insan davranış biçimleri ile ilişkisi vardır (Tunçok Sarıberberoğlu, 2018).

Dizim birbirinden farklı mekânsal düzenlemelerin oluşturulabilmesi için gerekli kurallar bütünü olarak tanımlanırken (Hillier ve Hanson, 1984), mekânsal dizim, mekânı üreten kuralların ve kısıtlamaların anlaşılmasının mekânsal biçimi anlamak için gerekliliği üzerinde durmaktadır. Teori mekâna dair çeşitli sayısal şemalar ile mekân-davranış ve algı çerçevesinde ortaya çıkan sosyal ve kültürel farklılıkları tanımlamaya olanak sağlamaktadır.

Kent ölçeğinden tekil bina ölçeğine fark etmeksizin, eşgörüş alanı (isovist area), merkezilik (circularity), kompaktlık (compactness), bütünleşme (integration), derinlik (depth), bağlantısallık (connectivity), kapsayıcılık (inclusivity), gibi kavramlar üzerinden şemalaştırılan mekânlar, dijital olarak sayısal bir değer alarak söz konusu mekânların grafik olarak temsil edilebilmesini ve konfigürasyon değerlerinin istatistiksel olarak başka mekânsal verilerle karşılaştırılabilmesine olanak sağlamaktadır.

Dizim teorisindeki kavramların en temeli sayılabilecek eşgörüş alanı ve eşgörüş çevresi değerleri insanın herhangi bir mekânda bulunurken kendi etrafinda 360 derece dönüş ile görsel olarak hâkim olduğu bütün alanı ve o alanın çevresel değerlerinin sayısal karşılıklarını tanımlamaktadır. Bu veriler bize mekânın biçimsel olarak uzun ya da ince olmasını ortaya çıkartırken davranış verileri ile değerlendirildiğinde mekânsal görülebilirlik görsel erişilebilirlik- üzerinden mekânı ele almaya imkân tanımaktadır. Doğrusal mekânların ve o mekânlara eklemlenen diğer ara mekânların dizimsel değerleri ile insan davranış biçimlerinin içerik ve yoğunluklarının birbirleri ile anlamlı ilişkisi olduğu varsayılmaktadır.

Tunçok Sarıberberoğlu'nun (2018) gerçekleştirdiği Eğitim Binalarında Mekânsal Davranışın Dizimsel (Sentaktik) İrdelenmesi başlıklı doktora çalışması kapsamında lineer yerleşime sahip plan çözümlerinin görüş alanını arttırdığı ve dolayısıyla da sosyal etkileşimin olumlu bir biçimde mekânsal düzen tarafindan desteklendiği sonucu ortaya koyulmaktadır. Tarçın Turgay ve Ünlü (2017) ise fiziksel bileşenlerinin görsel/biçimsel olarak algılanmasının sosyal ortam ile ilişkili olduğunu; mekânın morfolojisinin nitelikleri üzerinden vurgulamaktadır. Bu bağlamda da doğrusal ya da organik doğrusal açık alanlara sahip bir kampüs yapılaşmasının oluşturduğu sokak etkisinin sosyal etkileşimi destekler niteliğge sahip olabileceğini öngörmek mümkündür.

Bütün bu biçimsel ve kavramsal veriler doğrultusunda söz konusu binanın tasarım aşamasında kent-kültür ve sosyal yaşam ekseninde çalışması hedeflenmiş olup bütüncül bir tasarım elde edilmesi amaçlanmıştır. Söz konusu bina kurgusundaki temel tasarım yaklaşımı ilerleyen bölümlerde sunulmaya çalışılmaktadır.

\section{TASARIM SÜRECİ}

Tasarım süreci kapsamında tasarım probleminin mekânsal kimlik gereksinimleri irdelenmiş ve mekânsal işlevlerin mekânsal düzene dayalı gereksinimleri göz önünde bulundurulmuştur. Tasarlanması hedeflenen mekânların işlevsel ve anlamsal karşılıkları konunun sahip olduğu sosyal, kültürel ve ekonomik beklentiler üzerinden sorgulanmış ve karar aşamasında eğitim birimlerinin biçim arayışlarının yanı sıra öğrenci-akademisyen-kentli etkileşimini destekleyen bir ortamın oluşturulması hedeflenmiştir (Şekil 3).

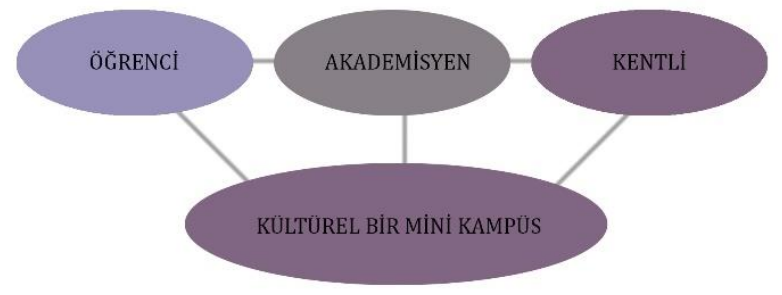

Şekil 3. Tasarıma dair ilişki şeması

Bu bağlamda analiz ve tasarım aşaması ile başlatılan süreç, mekânsal ve işlevsel veriler üzerinden şekillenmiştir. Kullanıcı ihtiyaçlarının belirlenmesi ile başlatılan tasarım süreci ise, kavramsal yaklaşım ve biçim ilişkisi kurularak tamamlanmıştır.

\section{Proje Alanı}

D-750 Karayolu üzerinden Zonguldak İl'ini D-100 Karayoluna bağlayan yol güzergâhı üzerinde kurulu olan Mengen ilçe merkezi yerleşim alanı itibariyle bir vadi görünümü taşımaktadır. Bolu Abant İzzet Baysal Üniversitesi'nin ana kampüsü olan Gölköy yerleşkesi Bolu ilinde yer alırken, Mengen ilçesinde yer alan Meslek Yüksek Okulu konaklama, eğitim ve sosyal birimleri ile ilçe içinde dağınık bir yerleşim göstermektedir (Url-1). Bolu ili Mengen İlçesi Konak Köyü Cazlar Mevkiinde yer almakta olan proje alanı (Şekil 4), konum olarak ilçe merkezine yakın dış çeperde, Mengen ilçesi özelinde gelişme bölgesi içerisindedir (Url-2). Söz konusu proje kapsamında da gerçekleştirilen tasarım ilçe içinde bir 
merkez niteliği taşıması hedeflenen bir mini bir kampüs kurgusu olarak karşımıza çıkmaktadır.

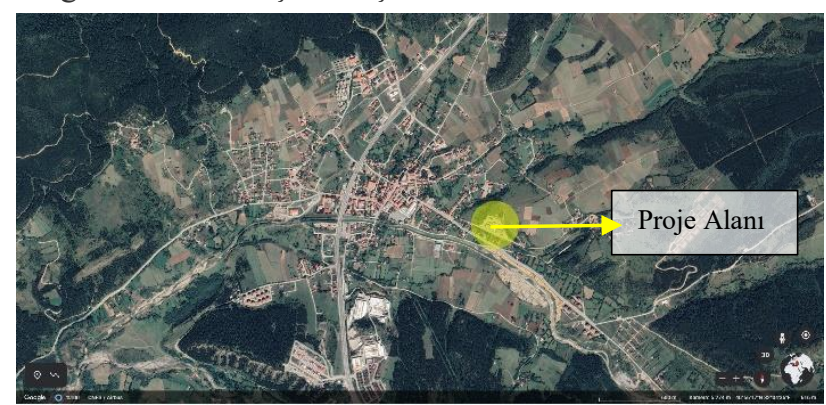

Şekil 4. Proje alanı

\section{İhtiyaç Programı}

İhtiyaç programı tasarım aşamasının bir diğer önemli aşamasını oluşturmaktadır. Gerçekleştirilen ihtiyaç programı kurgusunda öncelikli olarak ilçede yer alan meslek yüksek okulu ögretim üyelerinin tespit ettikleri gereksinimler üzerinden bir şema oluşturulmaya çalışılmış, süreç içinde dâhil olan belediye ve sosyal kurumların da katılımı ile Mengen'in sahip olduğu aşçılık ve gastronomi geleneğinin devam etmesi adına festivallerin ve diğer etkinliklerin desteklenebileceği ana ve ara mekânlara ihtiyaç vurgusu yapılmıştır. Eğitim, idari ve sosyal alanlar olarak üç ana kategoride indirgenen kurgu; Gastronomi Bölümü, Aşçılık Bölümü, Sosyal Tesis, Konaklama (Yurt) Birimi, Açık-Kapalı Spor Alanları ve Teknik alanların bulunduğu bir Karşılama yapısı ile alt birimler üzerinde ele alınmıştır (Çizelge 1).

Çizelge 1: İhtiyaç programı

\begin{tabular}{|c|c|c|}
\hline \multirow[b]{14}{*}{ Eğitim Alanı } & Gastronomi & Așçılık \\
\hline & Uygulama & Uygulama \\
\hline & Mutfakları & Mutfakları \\
\hline & 120 ve 160 Kişi & 120 ve 160 Kişi \\
\hline & Kapasiteli Amfi & Kapasiteli Amfi \\
\hline & Derslikler & Derslikler \\
\hline & Pasta Ekmek Lab. & Pasta Ekmek Lab. \\
\hline & Ar-Ge Lab. & Şeker Dekor Lab. \\
\hline & $\begin{array}{l}\text { Yüksek L. } \\
\text { Derslikleri }\end{array}$ & Bilgisayar Lab. \\
\hline & Duyu Analiz Lab. & - \\
\hline & Öğr. Gör. Odaları & Öğr. Gör. Odaları \\
\hline & İdari Birimler & İdari Birimler \\
\hline & $\begin{array}{l}\text { Öğrenci Giyinme } \\
\text { Odalar1 }\end{array}$ & $\begin{array}{l}\text { Öğrenci Giyinme } \\
\text { Odalar1 }\end{array}$ \\
\hline & Teknik Alanlar & Teknik Alanlar \\
\hline \multirow[b]{5}{*}{ Sosyal Tesis } & \multicolumn{2}{|l|}{ Konferans Salonu } \\
\hline & \multicolumn{2}{|l|}{ Kütüphane } \\
\hline & \multicolumn{2}{|c|}{ Öğrenci Kulüp Odaları } \\
\hline & \multicolumn{2}{|c|}{ Mescit } \\
\hline & \multicolumn{2}{|c|}{ Yemekhane } \\
\hline \multirow[b]{6}{*}{ Konaklama } & \multicolumn{2}{|c|}{80 (40 K + 40 E) Öğrenci Kapasiteli } \\
\hline & \multicolumn{2}{|c|}{ Yemekhane } \\
\hline & \multicolumn{2}{|c|}{$\begin{array}{c}\text { Serbest Çalışma Odası ve Ortak } \\
\text { Dinlenme Alanları }\end{array}$} \\
\hline & \multicolumn{2}{|c|}{ İdari Birimler } \\
\hline & \multicolumn{2}{|c|}{ Mescit } \\
\hline & \multicolumn{2}{|c|}{ Teknik Alanlar } \\
\hline & \multicolumn{2}{|c|}{230 Seyirci Kapasiteli Kapalı Salon } \\
\hline Spor & \multicolumn{2}{|c|}{ Tenis ve Basketbol Kort Alanı } \\
\hline
\end{tabular}

İmalat sürecinin Vakıf tarafindan finanse edilmesi nedeniyle ihtiyaç programı ve $\mathrm{m} 2$ kararlarında belirli kısıtlamalara gidilmesi söz konusu olmuş, mimari program oluşumu aşamasında en temel gereksinimlerin karşılanmasının birincil hedef olarak belirlenmiştir.

\section{Tasarım Kararları}

Eğitim binası özelinde bir tasarım problemi olan Aşçılık ve Gastronomi Eğitimi Kampüsü projesi, tekil bina çözümlemelerinin yanı sıra bütüncül bir mini kampüs sistemi ile alınmıştır. Yaklaşık $21.300 \mathrm{~m} 2$ alana sahip olan proje arsasında ana yerleşim kararlarında arazinin ana ulaşım yoluna dik eğimi en etkin faktörü oluşturmaktadır. Söz konusu tasarım kapsamında da arazinin eğim ile paralel olan doğrusal biçimi genel kampüs kurgusunun da yer yer doğrusal yer yer de organik doğrusal şekillenmesine olanak sağlamıştır. Görsel etkileşimin desteklendiği dizimsel bağlamda doğrusal yaklaşım ile sosyal etkileşim potansiyelinin de arttırılması hedeflenmiştir.

Alan birbirinden bağımsız çalışması beklenen eğitim birimlerinin (Gastronomi ve Aşçılık) hem kendi özel alanlarına sahip olmaları hem de ortak bir geçiş alanı ile ihtiyaç halinde birlikte kullanılabilmesi adına yine doğrusal bir formda birbirleri ile ilişkili kurgulanmıştır. Eğitim birimleri için yaklaşık $10.000 \mathrm{~m} 2$ inşaat alanı öngörülmüş olup mekânsal organizasyon ilişkileri ön planda tutulmuştur. Her katın içeriği sahip olması beklenen işleve göre şekillenmiştir.

Yaklaşık $3.000 \mathrm{~m} 2$ inşaat alanına sahip olan Sosyal Tesis ise her iki binanın da eşit ulaşıma sahip olduğu ve eğim sayesinde ortaya çıkan manzara ile ilişkili olacak şekilde ele alınmıştır. Bununla birlikte, Konaklama ile Spor alanlarına doğrusal yürüyüş aksının devamında yer verilerek açık festival alanının tanımlı bir alana dönüşmesi hedeflenmiştir (Şekil 5).

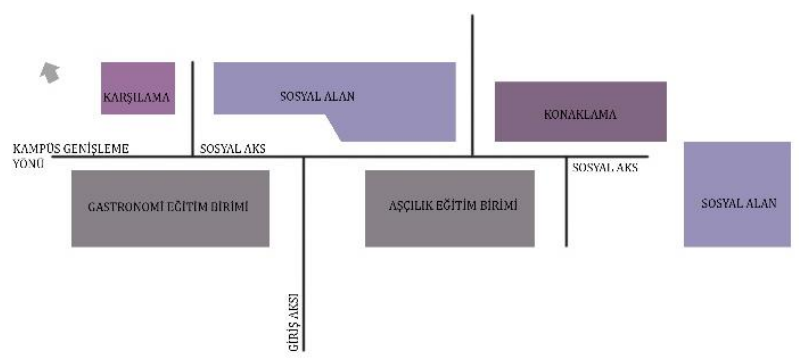

Şekil 5. Yerleşim şeması

$\mathrm{Bu}$ genel yerleşim genel planı birbirini takip eden ve eğim ile kademeli bir paralellik oluşturma prensibi üzerinden şekillenmiştir. Alanın Doğu-Batı yönünde gelişim planı kapsamında yer alması da ilerleyen süreçlerde bu tasarım ile tanımlanan doğrusal sosyal aksın devam edebilmesi adına bir alt gerekçe oluşturmaktadır.

Alanın kurgusunda erişilebilirlik kavramı ön planda tutulmuş olup, bu kavram fiziksel erişilebilirliğin yanı sıra görme/görülme, ulaşma/ulaşılma gibi sosyal etkileşimin destekleneceği morfolojik bir sistem olarak ele alınmaya çalışılmıştır. 


\section{Kat Plan Kurgu Kararları}

Arazideki yaklaşık \%15'lik olan ve güneyden kuzeye doğru yer alan eğim faktörü ana yerleşim kararlarında etkin bir role sahiptir. Arazinin en düşük noktasında itibaren üst kotlara doğru hiyerarşik bir düzen elde edilmeye çalışarak hedeflenen yatay sosyal sirkülasyonun düşeyde de desteklenmesi hedeflenmiştir. Düşük kot alanları özel eğitim alanları (uygulama mutfakları- ar-ge laboratuvarları, vs.) olarak değerlendirilirken, sosyal aks olarak ele alınan zemin kat alanı derslik ve sosyal alan sirkülasyonu ile desteklenmeye çalışılmıştır. İdari birimler ise üst katlarda yer alarak ana hareketten uzak ama manzaraya hâkim konumlandırılmıştır (Şekil 6).
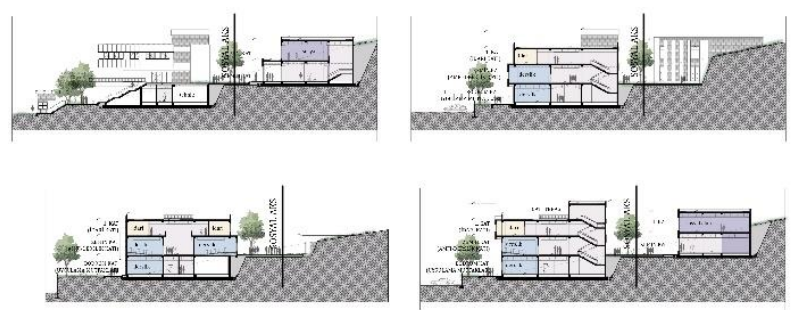

Şekil 6. Arazi ve kütle yerleşim ilişkisi

Arazide eğimin en alt seviyesinde konumlandırılan eğitim birimlerinin tasarım kurgusunda bodrum katta cephe imkânı sağlayan güney batı yönünde uygulama mutfaklarına yer verilmiştir. Toprak altında kalan kısımlar ise teknik alanlar ve laboratuvar alanları olarak kurgulanmıştır. Aşçılık ve Gastronomi Binaları bu kotta ara geçiş holü ile birbirine bağlanarak uygulama mutfaklarında kesintisiz harekete olanak sağlanması hedeflenmiştir (Şekil 7).

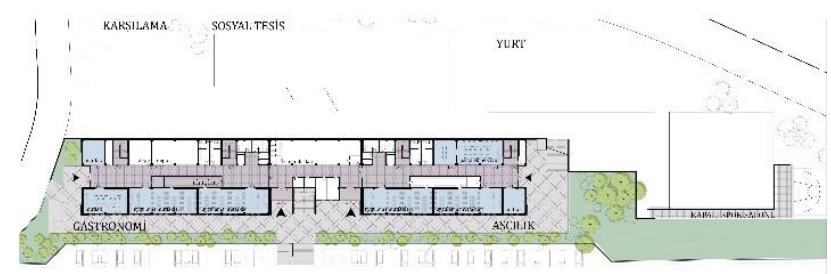

Şekil 7. Eğitim birimleri bodrum kat planı yerleşim ilişkisi

Uygulama mutfaklarının genel eğitim programı ile kurdukları ilişki hem özel hem genel kullanım bağlamında da öne çıkmaktadır. Mutfaklara arazinin en alt kotu olan güney batı yönünden doğrudan erişimin sağlanması ile kent merkezine gerçekleştirilen festival vb. ekinlikler için hazırlıklar amacı ile de bu mekânların kontrollü kullanıma olanak sağlaması ve olası acil durumlar için kolay tahliye yapılabilmesi hedeflenmiştir.

Arazinin ara kotunda oluşturulan yaya yürüyüş aksı ile alan içindeki bütün binaların birbiri ile ilişki kurması hedeflenmiştir. Alanın güney batısından verilen kampüs girişinden gelen yaya hareketinin iki bloğun arasında konumlanan merdivenler ile üst kota taşınması amaçlanmıştır. $\mathrm{Bu}$ ana kamusal merdivenin iki yanında da alt katlardan yine uygulama mutfaklarına geçiş sağlanmıştır.

Zemin kat olarak tanımlanabilecek olan kamusal kotta her iki eğitim binası için olması hedeflenen derslik birimleri ve sosyal tesis giriş alanı yer almaktadır. Alt giriş kotundan gelen ana merdiven birincil meydan olarak tanımlanan alana çıkmakta ve her iki eğitim binası ile sosyal tesisi birlikte karşılamaktadır. Bu sayede de ana dolaşım aksı üzerinde karşılaşma alanları kurgulanarak sosyalleşme parametrelerinin zenginleşmesi hedeflenmiştir. Bu kotta yer alan kurgu kampüs alanındaki ana hareketin akışkanlığı üzerinde kurgulanmıştır. Doğrusal yaya aksı ile bütün kampüs alanının hem görsel hem de hareket üzerinden deneyimlenmesi ana tasarım hedefini oluşturmaktadır (Şekil 8).

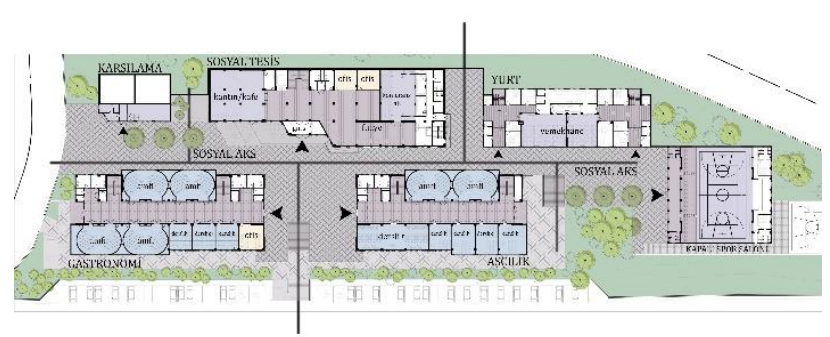

Şekil 8. Zemin kat planları- sosyal aks ilişkisi

Arazinin kuzeyine konumlandırılan sosyal tesis kütlesi ile öğrenci sosyal hayatının etkin bir biçimde kampüs alanı geneline hâkim olması amaçlanmıştır. 250 kişilik bir konferans salonuna sahip olan bu bina, gelecekte gösteri mutfağı eklenerek kullanılması hedeflenerek kurgulanmıştır. Öğrencilerin ve akademisyenlerin eğitimlerinin yanı sıra kentlinin de yararlanacağı düşünülerek, alanın sosyal aks üzerinden erişime olanak sağlaması hedeflenmiştir. Zemin katta yer alan kafeterya/kantin alanı da yine konferans salonu fuayesine destek olacak biçimde sosyal aks üzerinde yer almaktadır.

Uygulama projeleri kapsamında çalışılmayan fakat avan proje düzeyinde birakılan konaklama biriminde ise zemin katta kız ve erkek öğrenciler için doğu batı yönünde ayrı girişler kurgulanmış olup, iki girişin kesişiminde sosyal aks ile görsel etkileşime sahip yemekhane ve kafeterya gibi sosyal mekânlara yer verilmiştir. Yine bu kotta sosyal aks kapalı spor salonu ile sonlandırılarak hareketin ana bir mekânda toplanması amaçlanmıştır. Yine bu bina da ilk aşamada uygulama projesi yerine avan proje düzeyinde birakılmıştır.

Eğitim bloklarında bir üst kotta eğitim birimlerinin idari birimleri yer almaktadır. Her iki blokta da son kat olan bu katta dekanlık holü güney batı yönünde konumlandırılmıştır. Bu karar ile idari birimler katında oluşturulan galeri boşluğu ile derslik katının görsel etkileşim içerisinde olması önemsenmiştir. Bu sayede idari ve akademik alanın hem işlevsel olarak hem de sahip olduğu anlamsal duruşu nedeniyle bina içindeki alanlara hâkim bir konumda olması hedeflenmiştir. Sosyal tesisin üst katında ise yine manzaraya hâkim kütüphane, öğrenci kulüpleri, yemekhane ve mescit alanları yer almaktadır (Şekil 9).

Eğitim ve Sosyal Tesis binalarının yanı sıra sosyal aksın devaminda yer alan konaklama biriminin de zemin kat kurgusunun sosyal etkileşimi destekler niteliğine rağmen üst katta eğitim blokları gibi mekânsal özelleşmeye gidilmiştir. Zemin kat kurgusunda öğrencilerin yemekhane ve serbest çalışma mekânları yer alırken, üst katlarda özel konaklama odaları yer almaktadır. Bu bina özelinde de 
mekânsal kurgu zemin kattan başlayarak genelden özele bir işlevi takip etmektedir.

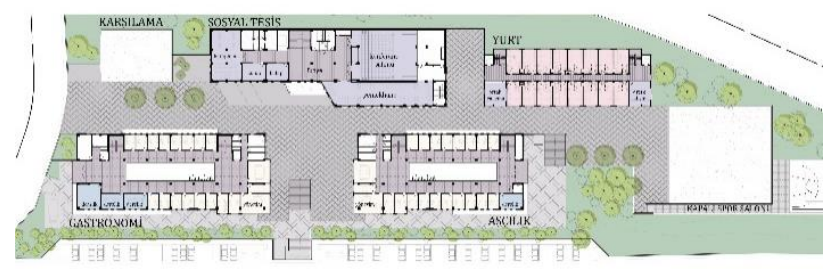

Şekil 9. 1. kat plan yerleşim ilişkisi

Alanın genel kurgusu değerlendirildiğinde doğudan güney batıya doğru şekillenen doğrusal hareketin yanı sıra kuzeyden güneye doğru da organik doğrusal bir akış sağlanmaya çalışıldığını söylemek mümkündür. Karşılama birimi ile başlayan ve yer yer daralıp yer yer genişleyen sosyal aks ile oluşturulan yaya hareketinin Kapalı Spor Salonu ile sonlanması hem de gerekli olacak geniş kapasiteli diğer sosyal aktivitelerin gerçekleştirilebilmesi hem öğrencilerin fiziksel aktivitelerini desteklemesi adına önemlidir. Tamamen açık kurgulanan kamusal sosyal aksin bu yapı ile sonlandırılması, festival kurgusu bağlamında da ele alınmıştır. Yine burada da mekânsal hiyerarşi genelden özele (açık kamusal alandan kapalı kamusal alana) değerlendirilerek, bu mekân içinde özel gösterimlerin yapılabilmesi hedeflenmiştir (Şekil 10).

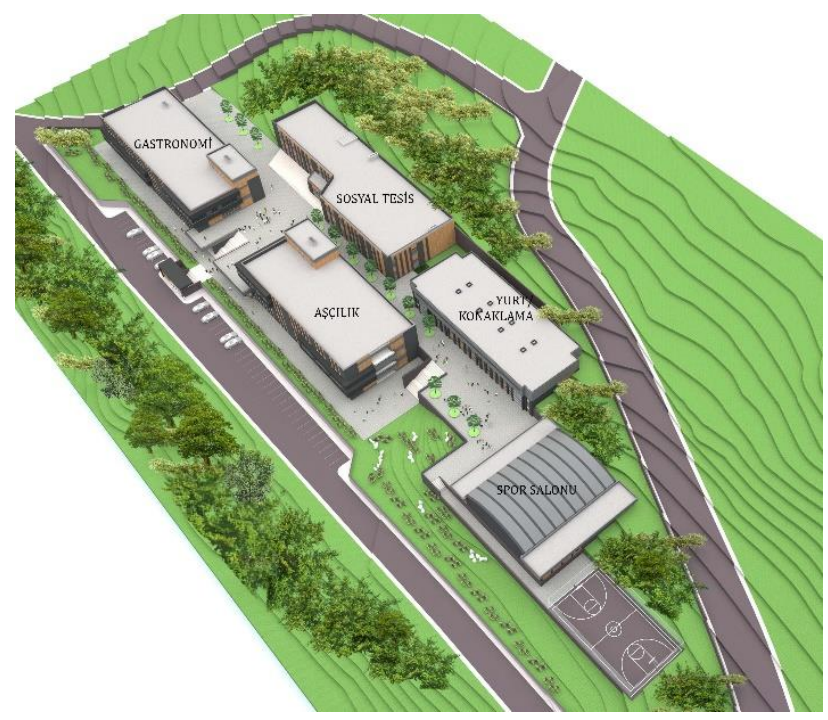

Şekil 10. Genel yerleşim kurgusu

Cephe Kararları

Mengen ilçesi 5411 kişi ilçe merkezi olmak üzere toplam 16.504 kişi nüfuslu bir yerleşim yeridir (Url-4). Kent merkezinde bina dili olarak gelenekselden günümüz mimarisine çeşitli yaklaşımların belirli bir kural ve düzen olmadan uygulandığı görülebilmektedir. $\mathrm{Bu}$ nedenle de yörenin net tanımlı korunan bir yapı diline sahip olduğunu söylemek mümkün değildir (Şekil 11).
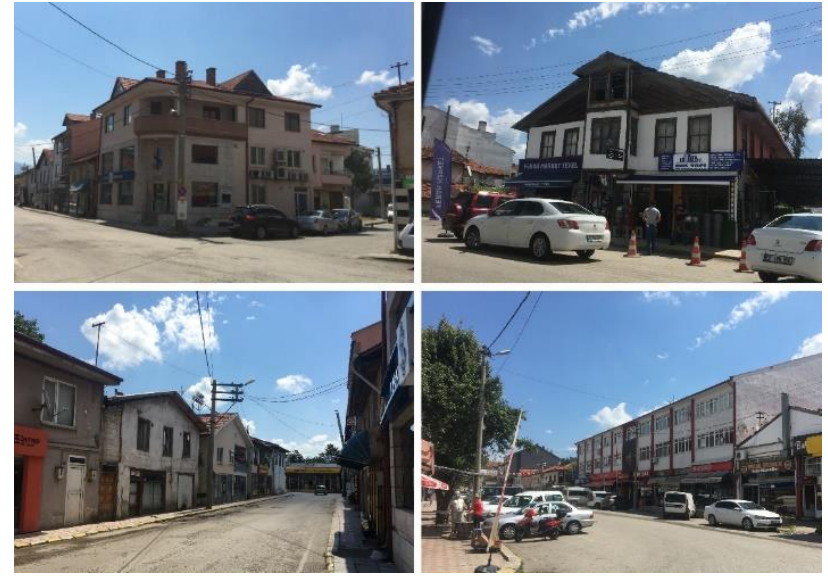

Şekil 11. Kent merkezi (F: Tunçok Sarıberberoğlu)

Tasarım aşamasında cephe kararları alınırken alan ve binanın tasarım probleminin sahip olduğu gelenekten geleceğe kavramsal duruşu bir bütün olarak değerlendirilmiş; geleneksel bir malzeme olan tuğla kaplama ile günümüz malzemelerinden sayılabilecek olan kompozit kaplama sistemlerinin bir arada kullanılması uygun görülmüştür. Alanın ve yapılaşmanın sahip olduğu doğrusal formun dengelenmesi adına da düşey elemanlar ile forma dayalı dengelenme sağlanmaya çalışılmıştır. (Şekil 12). Anadolu serisi tuğla renklerinin de siyah ve füme ton kompozit malzeme ile ön plana çıkarak dengeli bir görünüşe sahip olması hedeflenmiştir.

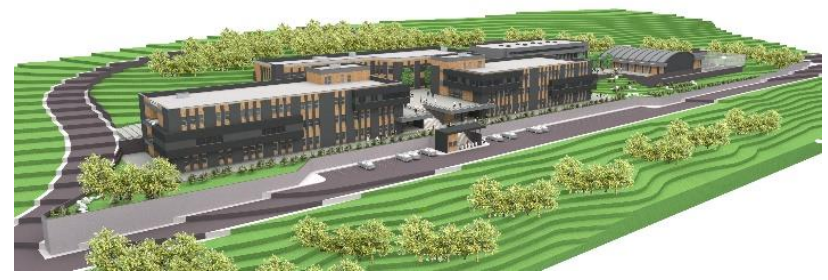

Şekil 12. Model görünüş

\section{DEĞERLENDİRME ve SONUÇ}

Eğitim binaları kampüs yaşantısı içinde fiziksel ve imgesel varoluşları gereği farklı nesillere ev sahipliği yaparak mekânsal hafiza oluşturan alanlardır (Tunçok Sarıberberoğlu, 2020). Alanın ve yapıların tasarım aşamalarında azami olan fiziki ihtiyaçların karşılanabilmesi ile birimler ve fonksiyonlar arası kurulan çok katmanlı sosyal-duygusal-algısal ilişkinin de güçlü olabilmesi amaç edinilmiştir. Kampüs kurgusunun yöre halkının da sosyal, kültürel ve ekonomik beklentilerini karşılaması, oluşturulan açık alan kurgusu ile kent merkezinde gerçekleştirilen festivalin bir ayağının da bu alanda yer alarak zenginleşmesi hedeflenmiştir. Bolu Abant İzzet Baysal Üniversitesi, Mengen Aşçılık ve Gastronomi Kampüsü mimari proje çalışması üzerine odaklanan bu çalışmanın, geleneklerden beslenen ve aynı zamanda da geleceğe yön verme hedefinde olan bir eğitim anlayışının mekânsal ihtiyaçlarının ilişkiler ağının temeli olan mekânsal organizasyon ve kavramsal yaklaşım ilişkisinin kurgulanmasına bir örnek olarak değerlendirilebileceği düşünülmektedir. 
Alan içinde yer alması planlanan yapıların eğitim ve sosyal merkez birimleri 2021 yılı itibariyle inşaat aşamasındadır (Şekil 13). Konaklama ve Spor Tesislerin ise ilerleyen süreçte uygulama projelerinin hazırlanması ve yapısal olarak uygulanması planlanmaktadır. Söz konusu alanın makale yazım aşamasında imalat sürecinde olması öngörülen tasarım kararlarının sınanmasına imkân tanımamaktadır. Fakat ilerleyen süreçte kampüs kurgusunun oluşturacağı sosyal yaşantı düzeyinin kavramsal yaklaşım aşamasında gözetilen dizimsel niteliklerinin davranışsal ve bilişsel analizler ile sınanması ile tasarım kararlarının hedeflerinin ne kadar gerçekleşebildiği görülerek eleştirel yaklaşımın sürdürülmesi mümkün olacaktır.

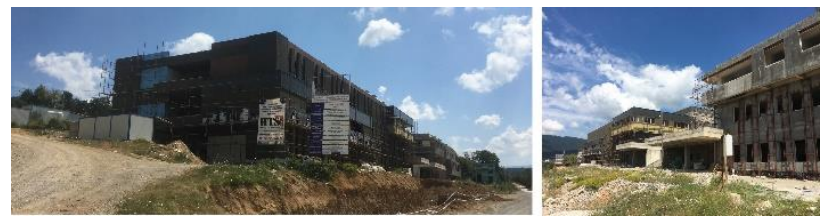

Şekil 13. Bina yapım süreci (24.07.2021)

\section{Teşekkürr ve Bilgi Notu}

$\mathrm{Bu}$ çalışma yazarın mimari proje müellifi olduğu Bolu Abant İzzet Baysal Üniversitesi Mengen Aşçıllı ve Gastronomi Eğitim Kampüsü Mimari Uygulama Projesinden üretilmiştir.

Makalede ulusal ve uluslararası araştırma ve yayın etiğine uyulmuştur. Çalışmada etik kurul izni gerekmemiştir.

Çıkar Çatışması Beyan Bilgisi

Herhangi bir çıkar çatışması bulunmamaktadır.

\section{KAYNAKÇA}

Ayvac1, G. (2009). Üniversite kampüslerindeki dış mekân tasarımında kullanıcı gereksinimlerinin belirlenmesine yönelik bir araştırma. Yayınlanmamış doktora tezi, İstanbul Teknik Üniversitesi. İstanbul.

Blank, F. (2003). Gastronomy. In S. H. Katz \& W. W. Weaver (Eds.), Encyclopedia of Food and Culture (pp. 102-103). Thomson.

Birinci, N., Erdoğan, S., ve Birol, G. (2020). Bir kamusal temas alanı olarak kampüs açık alanları: İzmir Demokrasi Üniversitesi kampüs tasarımı. Journal of Social and Humanities Sciences Research, 7(50), 232-240.

Birol, G. (2007). Bir kentin kimliği ve Kervansaray Oteli üzerine bir değerlendirme. Arkitekt Dergisi. Kasım-Aralık 2007. Say.514:46-54.

Broussard, E. (2009). The power of place on campus. Chronicle of Higher Education 55 (34), 12-13.

Düzenli, T., Mumcu, S. ve Akyol, D. (2017). Üniversite kampüsü açık mekânlarının gençler tarafindan kullanım amaçlarının belirlenmesi. Journal of International Social Research, 10(49).

Erçevik, B., Önal, F. (2011). Üniversite kampüs sistemlerinde sosyal mekân kullanımları. Megaron, 6(3).
Erdem, Ö., Mizrak, M. ve Aratoğlu, C. (2018). Festivallerin bölge turizmine katkıları ve sürdürülebilirliği: Uluslararası Mengen Aşçl1ık ve Turizm Festivali örneği. Journal of Tourism and Gastronomy Studies, 228, 245.

Erkman U. (1990). Büyüme ve Gelişme Açısından Üniversite Kampüslerinde Planlama ve Tasarım Sorunları, İ.T.Ü. Mimarlık Fakültesi, İstanbul.

Friedman, A., Zimring, C., ve Zube, E., (1978). Outdoor spaces, in Environmental Design Evaluation, Plenum Press, New York \& London.

Gehl, J. (1987). Life Between Buildings, Van Nostrand Reinhold, New York.

Griffith, J. (1994). Open Space Presercation: An Imperative For Quality Campus Environments, The Journal of Higher Education, vol. 65(6), p.645-669.

Hillier, B., Hanson, J. (1984). Buildings and Their Genotyps, in The Social Logic of Space, Cambridge University Press.

Hoşcan, N., Genç, K. ve Şengül, S. (2016). Bolu kent markası oluşturma sürecinde aşçılık kültürü ve gastronomi turizminin önemi: Bolgamer önerisi. Journal of Tourism and Gastronomy Studies, 4(Special issue 1), 52-76.

Kol, H. D. (2003). Beş yıllık temel eğitim yapılarının sekiz yıllık temel eğitim sitemine fiziksel adaptasyonunun değerlendirilmesi. Yayınlanmamış yüksek Lisans Tezi, Selçuk Üniversitesi, Konya.

Norberg-Schultz, C. (1980). Genius Loci: Towards a Phenomenology of Architecture. New York: Rizzoli.

Öney, H. (2016). Gastronomi eğitimi üzerine bir değerlendirme. Selçuk Üniversitesi Sosyal Bilimler Enstitüsü Dergisi, (35), 193202.

Perkins, B. (2002). Building Type Basics For Elementary and Secondary Schools. John Wiley \& Sons.

Sarışı1k, M., Özbay, G. (2015). Gastronomi turizmi üzerine bir literatür incelemesi. Anatolia. Turizm Araşstırmaları Dergisi, 26(2).

Seamon, D. (1982). The phenomenological contribution to environmental psychology. Journal of Environmental Psychology, 2, 119-140.

Seamon, D. (1987). Phenomenology and environmentalbehavior research. In E. Zube \& G.Moore (Eds.), Advances in Environment, Behavior, and Design. New York: Plenum

Tarçın Turgay, Z., Ünlü, A. (2017). Yere bağlılık ile mekân ilişkisinin bina ölçeğinde irdelenmesi: İstanbul Erkek Lisesi örneği, Uluslararası Hakemli Tasarım ve Mimarlık Dergisi, Aralı 2017 Sayı: 12, 40-74

Tunçok Sarıberberoğlu. M. (2018). Eğitim binalarında mekânsal davranışın dizimsel (sentaktik) irdelenmesi, Yayımlanmamış doktora tezi, İstanbul Teknik Üniversitesi, İstanbul.

Tunçok Sarıberberoğlu, M. (2020). Eğitim binası tasarımında mekânsal yaklaşımlar; Hukuk Fakültesi örneği. Artium, 8 (2) , 88-94.

Turner, P. (1990), Campus: An American Planing Tradition, The Architectural History Foundation/MIT Pres series no. 7

Whyte, W., (1980). The Social Life of Small Urban Spaces, The Conservation Foundation, Washington D.C.

Yalçın, A. E. (2012). Yer duygusu ve peyzaj değerleri arasındaki ilişkinin kampüsler üzerinde değerlendirilmesi, Yayımlanmamış 
Yüksek Lisans Tezi, Ankara Üniversitesi Fen Bilimleri Enstitüsü, 139 s. Ankara.

Yavuzçehre, P. S. (2016). Üniversitelerin kentlerine etkileri: Denizli Pamukkale Üniversitesi örneği. Süleyman Demirel Üniversitesi İktisadi ve İdari Bilimler Fakültesi Dergisi, 21(1), 235-250.

Yıldız, D., Şener, H. (2010). Binalarla tanımlı dış mekânların kullanım değeri analiz modeli. ITTÜDERGISII/a, 5(1).

Yılmaz, S. (2015). Bir kampüs açık mekânın çevresel tasarımı: Süleyman Demirel Üniversitesi Orman Fakültesi binas1. Kastamonu University Journal of Forestry Faculty, 15(2), $297-$ 307.

Url-1. http://www.mengen.gov.tr (erişim tarihi: 21.06.2021)

Url-2. https://mengen.bel.tr/ (erişim tarihi: 18.06.2021)

Url-3 https://mengen.gen.tr/mengen-tarihcesi-2 (erişim tarihi: 06.05.2021)

Url-4. https://bolu.ktb.gov.tr/TR-69933/mengen.html (erişim tarihi: 20.05.2021) 